\title{
RENDEMEN DAN KUALITAS MINYAK ATSIRI EUCALYPTUS PELLITA PADA BERBAGAI WAKTU PENYIMPANAN BAHAN BAKU
}

\author{
Ambar Tri Ratnaningsih, Enny Insusanty, Azwin \\ Fakultas Kehutanan Universitas Lancang Kuning \\ Jl. Yos Sukardo Km. 8. Pekanbaru \\ Email:ambar@unilak.ac.id, annovisa@yahoo.com, azwin@unilak.ac.id
}

\begin{abstract}
Forest harvesting waste in the form of Ecalyptus pellita leaves can be utilized to be essential oil by distillation process. The research aimed to 1) to know the effect of duration of leaf storage on yield and quality of essential oil produced, 2). Comparing the quality of E.pellita leaves essential oil with eucalyptus oil according to SNI. Methods taken by taking E. pellita leaf waste were then stored for 1,2,3,4,5 and 6 days then steam distillation and measured rendemen, specific gravity, sineol content and refractive index. The average oil yield of E.Pellita is $0.15 \%$ with the highest yield of $0.4593 \%$ in leaves stored for 3 days. The best essential oil quality comes from leaves that have been stored for 3 days with specific gravity of $0.9186,60 \%$ sineol content, refractive index 1.4603 and $80 \%$ alcohol solubility by $1: 1$.
\end{abstract}

Keywords: Eucalyptus pellita, oil volatile, rendemen, sineol, refractive index, solubility in alokol $80 \%$

\section{PENDAHULUAN}

Eucalptus pellita merupakan salah satu jenis tanaman unggulan Hutan Tanaman Industri (HTI) (Iskandar et al., 2003). Pada saat ini pemanfaatan $E$. pellita hanya pada bagian kayunya saja sedangkan bagian daun dibuang sebagai limbah yang tidak termanfaatkan. Daun E.pellita dapat dimanfaatkan sebagai produk hasil hutan bukan kayu (HHBK) dengan memanfaatkannya menjadi minyak atsiri. Daun Ecalypus memberikan manfaat yang cukup tinggi diantaranya estrak daunnya dapat dimanfaatkan menjadi bioherbisida dan minyak atsiri yang dihasilkan bersifat antibakteri terhadp bakteri Escherichia coli dan Staphylococcus aueus (Astiani et al., 2014), sebagai bahan obat untuk minyak gosok, sabun, obat kumur, permen, emulsi antiseptik, salep dan obat sakitgigi (Small, 2000). Pemanfaatan daun E. pellita menjadi minyak atsiri dilakukan dengan melakukan proses penyulingan bagian bunga, daun dan kulit batang tanaman (Damanik, 2009).

Ada beberapa faktor yang mempengaruhi kualitas dan kuantitas minyak atsiri yang dihasilkan dari daun diantaranya umur tanaman, tempat 
tumbuh serta perlakuan terhadap daun mulai dari pemetikan sampai dengan pemprosesan (Guenther, 1987). Limbah daun E. pellita yang dihasilkan pada proses pemanenan kayu pada umumnya dibiarkan di lapangan dan digunakan sebagai humus. Limbah ini dapat dimanfaatkan dengan mengangkut daun tersebut ke pengolahan limbah menjadi minyak atsiri. Proses pengangkutan limbah dari lokasi tebang ke proses pengolahan minyak atsiri membutuhkan waktu yang cukup lama. Oleh karena itu perlu adanya peneltian bagaimana pengaruh lama penyimpanan daun terhadap kualitas dan kuantitas minyak atsiri yang dihasilkan.

Kuantitas minyak atsiri yang dihasilkan ditunjukkan dari nilai rendemen yang dihasilkan dalam proses destilasi. Destilasi merupakan salah satu satu metode kimia-fisika yang digunakan untuk mengambil minyak atsiri. Prinsip penyulingan destilasi adalah pemisahan komonen-komponen suatu campuran yang terdiri atas dua cairan atau lebih berdasarkan perbedaan tekanan uap atau perbedaan titik didih komponen senyawa tersebut. Kualitas minyak atsiri E. pellita ditentukan oleh sifat fisikokimia minyak atsiri yang meliputi berat jenis, indeks bias, putaran optik, kadar sineol dan kelarutan dalam alcohol $80 \%$. Sifat fisiko -kimia tersebut dipengaruhi oleh lamanya proses penyimpanan daun sebelum dilakukan destilasi.

Penelitian ini bertujuan untuk 1) Mengetahui pengaruh lamanya penyimpanan daun E.pellita terhadap rendemen dan kualitas minyak atsiri yang dihasilkan, 2) membandingkan kualitas minyak atsiri daun E. pellita dengan minyak kayu putih sesuai SNI.

\section{METODE}

Penelitian dilakukan pada bulan Maret sampai Juli 2018. Daun yang digunakan dalam penelitian berasal dari HTI. PT. Perawang Sukses Perkasa Industri, Kabupaten Kampar Provinsi Riau. Pengujian kualitas E. pellita dilakukan di laboratorium Fakultas Kehutanan Universitas Lancang Kuning, Pekanbaru.

Bahan yang digunakan dalam penelitian adalah limbah pemanenan kayu berupa daun E. pellita yang telah disimpan dengan variasi penyimpanan $1,2,3,4,5$ dan 6 hari. Sedangkan peralatan yang digunakan adalah ketel penyulingan, gelas ukur, timbangan analitik, termometer. piknometer dan tabung reaksi. 
Proses destilasi dilakukan dengan menggunakan metode kukus air dan bahan yang disuling terpisah. Ketel penyulingan terbuat dari aluminium dengan kapasitas $10 \mathrm{~kg}$. Proses penyulingan berlansung Selama 5 jam. Rendemen minyak atsiri diketahui dengan membandingkan berat daun $E$. pellita sebelum dilakukan destilasi dengan minyak atsiri yang dihasilkan setelah penyulingan. Rumus yang digunakan adalah adalah

$$
\text { Rendemen }=\frac{\text { Output }}{\text { Input }} \times 100
$$

Keterangan :

$\mathrm{R}=$ Rendemen (\%)

Output = berat minyak $E$. pellita hasil penyulingan (gram)

Input = berat E.pellita yang disuling (gram)

Minyak E.pellita yang diperoleh dari hasil destilasi diuji kualitasnya dengan prosedur pengujian yang digunakan adalah SNI 01-5009-11-2001. Kualitas yang diuji adalah berat jenis, kadar sineol, indeks bias dan kelarutan dalam alkohol $80 \%$. Kualitas minyak E.pellita yang diperoleh dibandingkan dengan kualitas minyak kayu putih.

\section{HASIL DAN PEMBAHASAN}

\section{Rendemen Minyak Atsiri}

Rendemen minyak E.pellita diperperoleh dengan membandingan hasil minyak yang diperoleh dari hasil destilasi dengan bahan baku daun $E$. pellita yang digunakan. Jumlah minyak atsiri yang dihasilkan dari proses destiasi daun yang disimpan selama 1 , 2, 3, 4, 5 dan 6 hari bervariasi. Rendemen minyak atsiri dapat dilihat pada gambar 1 .

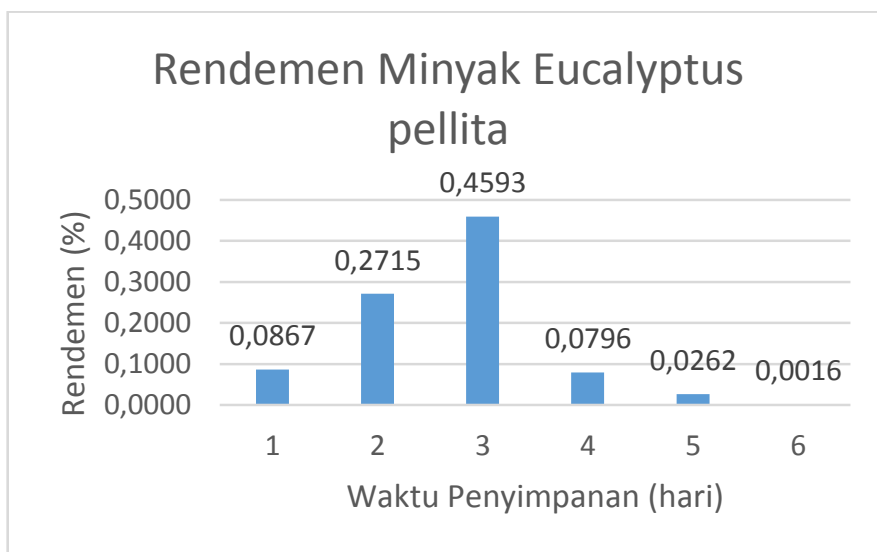

Gambar 1. Rendemen Minyak E.pellita

Pada gambar 1 diketahui adanya variasi nilai rendemen minyak atsiri E. pellita dengan waktu penyimpanan daun yang berbeda. Rendemen paling besar diperoleh setelah daun E.pellita disimpan selama 3 hari yaitu $0,4593 \%$, dan paling kecil setelah daun disimpan selama 6 hari yaitu $0,0016 \%$. Nilai rendemen minyak 
E. pellita lebih rendah jika dibandingkan dengan Eucalyptus deglupta sebesar 0,49\% ( Lukmandaru et al., 2004). Kandungan minyak E.pellita semakin meningkat pada penyimpanan daun hari pertama, kedua dan ketiga. Hal ini dimungkinkan oleh kadar air yang tinggi di dalam daun E. pellita yang mengalami waktu penyimpanan pendek yang menyebabkan jumlah daun yang sedikit pada berat yang sama jika dibandingkan dengan daun yang mengaami waktu penyimpanan yang panjang. Pada saat penyimpanan, terjadi penguapan air yang menyebabkan menurunkannya berat daun pada jumlah yang sama. Kadar air daun E. pellita pada beberapa lama penyimpanana dapat dilihat pada tabel 1.

Tabel 1. Kadar air daun E.pellita

\begin{tabular}{cccccc}
\hline \multicolumn{6}{c}{ Waktu penyimpanan daun (hari) } \\
\hline 1 & 2 & 3 & \multicolumn{1}{c}{4} & 5 & 6 \\
\hline 35,79 & 30,53 & 28,43 & 25,6 & 20,72 & 13,75 \\
$86 \%$ & $29 \%$ & $48 \%$ & $\begin{array}{l}616 \\
\%\end{array}$ & $35 \%$ & $20 \%$ \\
& & & &
\end{tabular}

Pada tabel 1 terlihat bahwa kadar air daun mengalami penurunan dengan semakin lamanya daun tersebut disimpan karena adanya proses penguapan.

Dalam penelitian ini destilasi yang digunakan adalah destilasi air dan uap dengan rata-rata rendemen minyak $E$. pellita sebesar $0,15 \%$. Nilai ini jauh lebih rendah jika dibandingkan dengan penelitian Astiani et al., (2014) yang mendestilasi E.pellita dengan metode destilasi uap mengasilkan rendemen sebesar 0,89\%. Metode destilasi akan mempengruhi nilai rendemen dari minyak atsiri.

\section{Berat Jenis}

Nilai berat jenis minyak atsiri didefisikan sebagai perbandingan antara berat minyak dengan berat air pada volume air yang sama dengan volume minyak pada yang sama pula. Berat jenis minyak E.pellita pada beberapa lama penyimpanan daun dapat dilihat pada tabel 2.

Tabel 2. Berat Jenis Minyak E.pellita

\begin{tabular}{cccccc}
\hline \multicolumn{7}{c}{ Waktu penyimpanan (hari) } \\
\hline 1 & 2 & 3 & 4 & 5 & 6 \\
\hline 0,9023 & 0,9051 & 0,9186 & 0,9469 & 0,9608 & 0,9830 \\
\hline
\end{tabular}

Berdasarkan tabel 2 diketahui berat jenis minyak dari destilasi daun E.pellita sebesar 0,90-0,98. Berat jenis semakin meningkat dengan semakin lamanya daun $E$. pellita disimpan. Berat jenis minyak $E$. pellita hampir sama dengan minyak Eucalyptus lain yaitu Eucalyptus deglupta sebesar 0,89 (Lumkandaru et al., 2004), E. 
polybractea (0,92-093), E. Australia $(0,90)$ dan $E$. urophylla $(0,81)$ (Guenther, 1949,1972)

Nilai berat jenis merupakan salah satu kriteria penentuan mutu dan kemurnian minyak atsiri. Jika dibandingkan dengan minyak kayu putih berdasarkan standar SNI 01-5009.112001, maka dapat diketahui minyak kayu putih memiliki berat jenis 0,9-0,93 sedangkan berat jenis yang didapat dari hasil pengujian minyak E.pellita dari daun yang disimpan 1,2 dan 3 hari 0,90-0,91) masuk kedalam standar SNI minyak kayu putih. Berat jenis minyak E.pellita dari daun yang disimpan 4,5 dan 6 hari sebesar 0,94-098 dan memiliki nilai yang lebih besar dari standar SNI minyak kayu putih.

Apabila nilai berat jenis dari minyak terlalu tinggi atau terlalu rendah, dapat dipastikan adanya senyawa lain yang tidak seharusnya berada di minyak tersebut (Safwani, 2015). Selain itu adanya kotoran yang masuk ke dalam minyak atsiri akan mempengaruhi perubahan berat jenis (Siarudin dan Widiyanto, 2014).

3. Kadar Sineol

Kadar sineol merupakan prasyarat khusus bagi minyak euclyptus.
Sineol merupakan terpenoid yang banyak terkandung dalam minyak atsiri. Aroma minyak $E$. pellita hampir sama dengan minyak kayu putih karena adanya senyawa sineol. Dalam penelitian ini untuk menentukan kadar sineol $\left(\mathrm{C}_{10} \mathrm{H}_{18} \mathrm{O}\right)$ minyak $E$. pellita digunakan metode kristalisasi. Kadar sineol minyak E.pellita pada dari penyimpanan daun $1,2,3,4,5$ dan 6 hari dapat dilihat pada tabel 3 .

Tabel 3. Kadar Sineol Minyak E.pellita

Waktu penyimpanan daun (hari)

\begin{tabular}{llllll}
\hline 1 & 2 & 3 & 4 & 5 & 6
\end{tabular}

$\begin{array}{llllll}25 \% & 50 \% & 60 \% & 75 \% & 25 \% & 25 \%\end{array}$

Pada tabel 3 dapat dilihat bahwa kadar sineol minyak E.pellita meningkat dengan semakin lamanya daun disimpan (1,2,3,4 hari) sebelum proses destilasi. Tetapi pada saat daun disimpan selama 5 dan 6 hari kadar sineol mengalami penurunan. Nilai ratarata kadar sineol minyak E.pellita sebesar $43,33 \%$. Nilai ini mendekati sama dengan penelitian Damanik (2009) yang menyatakan kadar sineol E. urophylla sebesar $45 \%$.

Berdasarkan standar minyak kayu putih 01-5009.11-2001, minyak minyak kayu putih dengan kadar sineol 
$\geq 55 \%$ termasuk dalam kelas mutu $U$ (utama) dan mutu $\mathrm{P}$ (pertama) jika kadar sineol kurang dari 55\%. Sineol merupakan senyawa kimia golongan ester turunan terpen alkohol yang terdapat dalam minyak atsiri. Semakin besar kandungan sineol pada minyak atsiri kayu putih maka semakin baik mutu dari minyak atsiri kayu putih tersebut (Sumadiwangsa et al., 1973)

Meskipun belum ada standar mutu kadar sineol minyak E. pellita, tetapi jika dibandingkan dengan standar minyak kayu putih dengan hasil penelitian diketahui penyimpanan daun E.pellita selama 3 dan 4 hari memiliki kadar sineol termasuk kelas mutu utama, sedangkan penyimpanan daun selama 1,2, 5 dan 6 hari termasuk kelas mutu pertama. Menurut hasil penelitian Astiani et al., (2014) (2014), senyawa utama yang terdpat dalam minyak atsiri E.pellita yaitu $\alpha$-pine $(10,41 \%), \beta$-pinen $(20,88 \%)$, bornylen $(6,74 \%)$, transkaryopilen (15,60\%), spatulenol (6,08\%) dan globulol $(7,67 \%)$

\section{Indeks bias}

Indeks bias merupakan ukuran yang menunjukkan pembiasan cahaya antara minyak dan udara. Indeks bias menunjukkan kemampuan seluruh kompen minyak atsiri untuk membiaskan cahaya yang terlewati dan merubah arah sudut dari garis normal. Parameter ini biasanya digunakan untuk mendeteksi pemalsuan awal minyak atsiri minyak kayu putih (Setyaningsih et al., 2014 dalam Safwani, 2015).

Dalam penelitian ini untuk mengetahui indeks bias digunakan Refraktometer. Nilai indeks bias yang dihasilkan minyak $E$. pellita pada beberapa lama penyimpanan daun dapat dilihat pada tabel 4 .

Tabel 4. Indeks Bias Minyak E.pellita

\begin{tabular}{cccccc}
\hline \multicolumn{6}{c}{ Waktu penyimpanan (hari) } \\
\hline 1 & 2 & 3 & 4 & 5 & 6 \\
\hline 1,460 & 1,463 & 1,460 & 1,465 & 1,470 & 1,4704 \\
0 & 0 & 3 & 5 & 4 & \\
& & & & & \\
\hline
\end{tabular}

Pada tabel 4 dapat diketahui indek bias minyak $E$. pellita semakin meningkat dengan semakin lamanya daun disimpan sebelum dilakukan proses destilasi. Rata-rata indeks bias E. pellita sebesar 1,4549. Jika dibandingkan dengan standar minyak kayu putih menurut SNI 01-5009.112001, dapat diketahui minyak kayu putih memiliki kisaran indeks bias antara 1,461,47 pada suhu yang sama sedangkan indeks bias yang didapat dari minyak $E$. 
pellita 1,46-1,47. Dari nilai indeks bias ini menunjukkan bahwa indeks bias yang didapat dari minyak E.pellita sama dengan minyak kayu putih.

Nilai indeks bias berbading lurus dengan kadar air yang terkandung dalam minyak tersebut, maka semakin tinggi dari indeks bias yang terkandung dalam minyak $E$. pellita semakin tinggi juga nilai kadar airnya. Minyak yang memiliki kadar air yang semakin besar dapat menurunkan mutu minyak.

\section{Kelarutan dalam Alkohol}

Minyak atsiri memiliki kemampuan untuk larut dalam alkohol pada perbandingan tertentu. Komponen kimia yang terkandung dalam minyak atsiri akan menentukan kelarutan minyak dalam alkohol. Hasil pengujian minyak $E$. pellita dari bahan baku daun yang disimpan pada beberapa waktu penyimpan sebelum didestilasi dapat dilihat pada tabel 5 .

\section{Tabel 5. Kelarutan Minyak E.pellita dalam Alkohol $80 \%$}

\begin{tabular}{cccccc}
\hline \multicolumn{7}{c}{ Waktu penyimpanan (hari) } \\
\hline 1 & 2 & 3 & 4 & 5 & 6 \\
\hline $1: 1$ & $1: 1$ & $1: 1$ & $1: 2$ & $1: 2$ & $1: 2$
\end{tabular}

Berdasarkan hasil pengujian kelarutan minyak $E$. pellita dalam alkohol $80 \%$ dapat dilihat bahwa minyak E. pellita memiliki kelarutan alkohol $80 \%$ dengan perbandingan 1:1 dan 1:2. Perbandingan 1:1 artinya dengan $1 \mathrm{ml}$ minyak $E$. pellita diperlukan $1 \mathrm{ml}$ alkohol untuk melarutkannya. Angka ini menunjukkan kecepatan daya larut dan kualitas minyak (Siarudin dan Widiyanto, 2014). Semakin besar tingkat angka perbandingan maka semakin mudah minyak E.pellita larut dalam alkohol maka akan semakin mempermudah minyak untuk diencerkan dalam pengolahan lebih lanjut. Pengenceran minyak dalam pengolahan lebih lanjut dari minyak ini akan dapat menurunkan biaya produksi sehingga dapat meningkatkan nilai ekonominya.

Menurut SNI 01-5009.11-2001 syarat kelarutan minyak kayu atsiri kayu putih dalam alkohol $70 \%$ adalah 1:1 sampai 1:10 jernih. Jika dibandingkan kelarutan minyak E.pellita yang dihasilkan dalam penelitian ini 1:1 -1:2 dengan minyak kayu putih maka diketahui minyak E.pellita memiliki kualitas yang sama dengan minyak kayu putih. Guenther (1987) menyebutkan bahwa semakin banyak senyawa terpen yang terkandung di dalam minyak atsiri kayu putih, maka minyak kayu putih tersebut akan semakin sulit larut dalam 
alkohol dibandingkan dengan minyak yang kaya senyawa hidrokarbon teroksigensi. Perubahan kelarutan pada minyak kayu putih bisa juga terjadi akibat adanya pencampuran minyak atsiri kayu putih dengan bahan lain atau pengaruh umur pohon penghasil kayu putih

\section{KESIMPULAN}

Dalam pengolahan daun E.pellita menjadi minyak atsiri dilakukan proses penyimpanan daun sebelum diolah. Lamanya penyimpanan daun mempengaruhi nilai rendemen dan kualitas minyak atsiri yang dihasilkan. Rata-rata rendemen minyak E.Pellita adalah $0,15 \%$ dengan rendemen tertinggi sebesar 0,4593\% pada daun yang disimpan selama 3 hari. Berdasarkan perbandingan kulitas minyak E.pellita dengan minyak kayu putih diketahui kualitas minyak yang paling baik berasal dari daun yang telah disimpan selama 3 hari dengan berat jenis sebesar 0,9186, kadar sineol 60\%, indeks bias 1,4603 dan kelarutan alkohol $80 \%$ sebesar $1: 1$.

\section{UCAPAN TERIMA KASIH}

Penulis mengucapkan terima
kasih kepada Fakultas Kehutanan

Universitas Lancang Kuning yang telah membantu dalam pendanaan penelitian ini. Penulis juga mengucapkan terima kasih kepada PT. Perawang Sukses Perkasa Industri yang telah memberikan izin dan fasillitas selama penelitian.

\section{DAFTAR PUSTAKA}

Astiani, D.P., A. Jayuska, S.Arrenez. 2014. Uji Aktivitas Antibakteri Minyak Ecalyptus pellita Terhadap Bakteri Escherichia coli dan Staphylococcus aureus. JKK.Volume 3.3. Hal 49-53.

Damanik, M., 2009., Kajian Minyak Atsiri Pada Ekaliptus (Eucalyptus urophylla) Umur 4 Tahun di PT Toba Pulp Lestari Tbk, Departemen Kehutanan Fakultas Pertanian, Universitas Sumatera Utara, (Skripsi)

Guenther, E.1949. The Essential Oil Vol. II. D.van Nostrand Company Inc., Princeton, New Jersey.

Guenther, E. 1990. Minyak Atsiri. Jilid IV A. Jakarta: Universitas Indonesia Press. Guenther, E. 1987. The Essetial Oils, diterjemahkan oleh S. Ketaren, Jilid Im 3-10, 171-183,286-292 296-299, UI press. Jakarta

Iskandar, U., Ngadiono dan A Nugraha. 2003. Hutan Tanaman Industri di Persimpangan Jalan. Arivco Press. Jakarta.

Small, B.E.J.2000. The Australian Eucalyptus Oil Industry on Overview. New South Wales department of Agriculture. Australia

Siarudin M dan Widiyanto,A. 2014. Karateristik Penguapan Air dan Kualaitas Minyak pada Daun Kayu Putih jenis Asteromyrtus Symphycrpa. Penelitian Hasil Hutan. 32(2): 139-150. 
Sumadiwangsa S, Sutarna MS, Siti H.1973. Pedoman Pengujian Kualitas Minyak Atsiri Kayu Putih. Jakarta (ID): Lembaga Penelitian Hasil Hutan Direktorat Jenderal Kehutanan Departemen Pertanian.

Safwani, SA. 2015. Profil Komponenen Volatil Minyak Atsiri Kayu Putih dari Berbagai Daerahdan Pengaruhnya TErhadap Profil Flavor Cajuputs Candy. Skripsi. Fakultas Teknologi Pertanian. Institut Pertaninan Bogor 